\title{
Penile Prostheses in Spinal Cord Injured Patients: Combined Psychosexual Counselling and Surgical Regimen
}

\author{
Bruce G. Green, M.D. ${ }^{1}$ and Stephen L. Sloan, Ph.D. ${ }^{2}$ \\ ${ }^{1}$ Director of Urology, Shepherd Spinal Centre (Georgia Regional Spinal Cord \\ Injury Centre) and Clinical Instructor in Urology, Emory University. ${ }^{2}$ Sexual \\ Therapist, Shepherd Spinal Centre, Atlanta, Georgia, U.S.A.
}

\section{Summary}

Since 1981, forty spinal cord-injured patients have received penile prostheses using a combined approach of early sexual counselling during the acute rehabilitative phase of injury, followed by implantation in suitable candidates no less than nine to twelve months following injury. Early counselling is begun in private and group sessions, and stresses reassessment of body image, sexuality and sexual alternatives. The penile prosthesis is mentioned briefly during the acute phase of rehabilitation. Further counselling at the patient's request following discharge from the unit identifies those patients with continued interest in a penile prosthesis. Suitable surgical candidates must (1) have a stable bladder program, (2) have had a recent urologic $X$-ray evaluation, (3) have sterile urine at the time of implantation, and (4) be free of decubiti. All preoperative patients undergo MMPI testing and are seen by a sexual counsellor. Both the semi-rigid and inflatable penile prostheses are offered to the patient with a thorough discussion along with printed material on the advantages and disadvantages of each prosthesis, as well as surgical and postoperative complications. Patients are given a preoperative parenteral antibiotic regimen along with supervised antibiotic cleansing of the genitalia. Surgical techniques for each prosthesis is discussed. Following surgery, the patients are continued on antibiotics and are instructed not to engage in intercourse for six weeks. They are also seen by a sexual counsellor postoperatively.

There have been a total of forty implantations; thirty-four patients having had semi-rigid implants and six inflatable prostheses. There have been three implants which necessitated removal secondary to infection; these were semi-rigid rod patients. There has been one paraphimosis which necessitated secondary circumcision. The patients were given a sexual questionnaire in order to determine whether they had realized their preoperative expectations of an implant as well as good partner acceptance. The results are described, and appear to be favourable. We stress the selection of good candidates for sexual implantation in order to lessen potential complications and insure good results.

Correspondence to:

Bruce G. Green, M.D., 6500 Vernon Wood Drive, Atlanta, Georgia 30328, U.S.A. 
Key words: Penile prosthesis; Psycho-sexual counselling; Spinal cord injury.

\section{Introduction}

In the last decade sexual rehabilitation in the spinal cord-injured patient (SCI) has assumed an increasingly dominant role in the overall rehabilitative process (Berkman, 1976; Cole, 1973; Eisenberg, 1976). The majority of SCI patients are young men and women faced with sexual doubts, fears and anxieties, which cannot be ignored, but must be dealt with early in the course of rehabilitation. In addition the development and subsequent improvement in prosthetics have opened a new world to the spinal cord-injured male in attaining an aspect of sexuality that was heretofore impossible (Golji, 1979; Light, 1981). At the Shepherd Spinal Center (Georgia Regional Spinal Cord Injury Center) psychosexual counselling helps to discover candidates suitable for implantation of a penile prosthesis.

\section{Materials and Methods}

In the last five years forty patients have received penile prostheses using the combined approach of early sexual counselling during the acute phase of injury followed by implantation in suitable candidates no less than nine to twelve months following injury. Older injuries were counselled at their request upon entry into the clinic system.

Early counselling is begun in private and group sessions and stresses the patient's level of injury with reassessment of body image as it relates to sexuality. The education involves the partner when available, and stresses the emotional aspects of sexuality as well as sexual alternatives other than penovaginal intercourse for gratification. The penile prosthesis is mentioned briefly during the acute phase. Further counselling at the patient's request following discharge from our unit identifies those patients exhibiting continued interest in a prosthesis.

Suitable surgical candidates must have

(1) stable bladder programs.

(2) have had recent urologic X-ray evaluation.

(3) have sterile urine at the time of implantation.

(4) be free of open skin lesions.

Patients are hospitalized twenty-four hours prior to implantation for intensive parenteral antibiotic loading and supervised antiseptic cleansing of the genitalia. A subcoronal incision is used to insert the semi-rigid prosthesis and a pubic incision to insert the inflatable penile prosthesis. Perineal incisions are not used for fear of faecal contamination. Following surgery the patient is continued on antibiotics for one week and instructed not to engage in intercourse for six weeks. Post-implantation psychological counselling occurs at the patient's request.

Forty patients received implants, twenty-eight paraplegics and twelve quadriplegics, thirty-one had complete lesions and nine incomplete. The youngest patient was twenty-one years and the oldest sixty, with a mean age of thirty-three. 


\begin{tabular}{lr} 
Table 1 \\
\hline Type of Implant \\
\hline Jonas (semi-rigid) & 25 \\
Small-Carrion (semi-rigid) & 7 \\
AMS-600 (semi-rigid) & 2 \\
Inflatable penile implant & 4 \\
Hydroflex inflatable & 2 \\
\hline
\end{tabular}

Thirty-four patients had implantation of semi-rigid rods while six underwent insertion of inflatable implant. (Table 1).

The average time of injury to implant was four years.

\section{Results and Complications}

Of the forty patients implanted, we were able to contact thirty-six patients or their families by phone or letter as of July 1985. Twenty-three were married at the time of implant and 13 were single. Three patients had extruded rods, all of which had happened more than two years post implantation. One patient had a paraphimosis which required circumcision. One patient with an inflatable penile prosthesis had a minor erosion through the fossa navicularis which spontaneously healed, and the device is now functioning adequately. There were no immediate postoperative complications.

Thirty-one patients admitted to having intercourse regularly and were pleased with their decision to have implants. We were able to speak to several partners and they confirmed their satisfaction as well. Three patients with Small-Carrion prostheses continued to have some concealment problems, but they were in the thirty-one patient group who expressed satisfaction with the implant. Four patients were dissatisfied; all had had semi-rigid implants and they stated that the rods were not rigid enough to sustain vaginal penetration. One wife was not satisfied. One patient had died but his wife stated that they had had regular intercourse.

\section{Discussion}

The potential for high complication rates in spinal cord-injured patients undergoing implantation has been pointed out by other authors (Rossier, 1984; Van Arsdalen, 1981). It is therefore imperative to select a group of patients who have self-esteem, motivation and general care of their activities of daily living. Psychosexual counselling in the acute injury phase followed by post-injury adjustment period allows the patient to redefine his sexuality in a psychological sense (Schuler, 1982). Only then can he accept the anatomical changes a prosthesis has to offer.

The patient sees a psychologist prior to urologic consultation. This reeducation process involves:

(1) a reassessment of his general sexual knowledge.

(2) a description of the various prosthetic devices.

(3) the effect the implant surgery may have on sensation and sexual functioning,

(4) reassurance that coitus following surgery will not harm either partner. 
(5) an opportunity to talk with previous penile implant patients.

The urologist can then focus on the technical aspects of the procedure with a description of the surgical techniques outlining the advantages and disadvantages of the various prosthetic devices, in order to help choose the implant most suited for the patient. We have not used the maintenance of an external appliance as a sole indication for implantation as suggested by other authors (Smith, 1980, Van Arsdalen, 1981).

Of the patients who had extrusion of the rods, one had a suprapubic catheter, one had a urethral stricture and one developed a pressure sore at the base of the penis pushing against the symphysis pubis secondary to severe curvature of the spine. All of these patients had Small-Carrion prostheses. The use of the malleable rods (Jonas, AMS-600) appears to reduce the incidence of erosion and extrusion problems. It is interesting that, in recent years, more patients appear to have an interest in the inflatable penile implant perhaps due to increased media coverage. One complication in an inflatable penile implant involved the appearance of one cylinder at the fossa navicularis. The patient was instructed not to inflate the prosthesis for one month. We have recently implanted several self-contained inflatable devices. These combine the simplicity of the semi-rigid device with the variability of the inflatable implant. It is interesting to note that there were no postoperative wound infections. We believe, as do others, that maintenance of sterile urine prior to implantation will reduce the risk factors as regards immediate postoperative wound infections (Rossier, 1984). In this series, all implants were performed by the same surgeon in a private practice setting, not in a teaching institution.

Of the patients who were not satisfied with the implants, all had attempted intercourse on a regular basis. All of these had the Jonas prosthesis and this fact prompted switching to a more rigid and wider AMS-600 semi-rigid prosthesis.

All patients satisfied with the prostheses were enthusiastic in their response as were many of their partners. They were freely willing to discuss the surgery and results with other potential candidates.

In this age of medical marketing and public awareness, one cannot overemphasize the importance of proper patient selection for those involved in the urologic and psychosexual care of the spinal cord-injured patient. This is not a procedure to be recommended indiscriminately to every patient who requests it. Rather, a systematic selection process involving the sexual counsellor and the urologist will help lessen the potential complications and insure a high degree of patient satisfaction.

\section{Résumé}

Depuis 1981 , on a implanté des prothèses péniennes sur 40 patients souffrant de lésions de la moelle épinière en utilisant l'approache qui consiste d'abord à guider le patient sur le plan sexual lors de la phase aiguë de rééducation, suivie de l'implantation de la prothèse chez les candidats qui s'y prêtent, pas plus tard que dans les 9-12 mois suivant l'apparition des lésions. Les premiers conseils d'orientation psychologique sont donnés au cours de séances privées et en groupe et insistent sur la remise en valeur de l'image corporelle, de la sexualité et des alternatives sexuelles. La prothèse pénienne est mentionnée brièvement lors de la phase aiguë de la rééducation. Des séances d'orientation psychologique ont lieu dès la sortie de l'hôpital et permettent d'identifier les patients qui envisagent la prothèse. Les candidats aptes à l'intervention chirurgicale doivent: 1) avoir une vessie stable; 2 ) 
avoir subi récemment une évaluation radiologique des reins; 3) avoir une urine stérile au moment de l'implantation et 4) ne pas avoir d'escarres de décubitus. Tous les patients candidats à l'opération subissent des examens MMPI et sont suivis par un sexologue. On propose aux patients le pénis semi-rigide et le modèle gonflable, cela accompagné d'une discussion approfondie avec brochures à l'appui décrivant les avantages et les inconvénients de chaque prothèse ainsi que les complications chirurgicales et post-opératoires. L'administration parentérale pré-opératoire d'antibiotiques aux patients est accompagnée d'un nettoyage des parties génitales aux antibiotiques, sous surveillance médicale. On aborde les techniques chirurgicales de chaque prothèse. Après l'intervention chirurgicale, les patients continuent à être mis aux antibiotiques et il leur est recommandé de ne pas avoir de relations sexuelles pendant six semaines. Ils continuent à voir un sexologue après l'intervention chirurgicale.

On a procédé en tout à 40 implantations; 34 patients ont reçu des implants semi-rigides et six des prothèses gonflables. 3 implants ont dû être retirés à la suite d'une infection. C'était le cas de patients ayant une prothèse à verge semi-rigide. Il y a eu un cas de paraphimosis qui a nécessité une circoncision secondaire. On a remis aux patients un questionnaire portant sur leurs rapports sexuels afin de déterminer si leur implant répondait à ce qu'ils attendaient de l'intervention et si la prothèse était bien acceptée par le partenaire. Les résultats seront décrits plus tard et semblent tout à fait favorables. Nous attachons énormément d'importance à la sélection de bons candidats à l'implantation sexuelle de façon à réduire les complications éventuelles et à assurer des résultats positifs.

\section{Zusammenfassung}

Seit 1981 haben 40 Patienten mit Rueckenmarkverletzungen Penisprothesen erhalten, wobei nach einer kombinierten Sexualberatung waehrend der Fruehphase der Rehabilitation der Verletzung die Implantation bei geeigneten Patienten fruehenstens 9 bis 12 Monate nach der Verletzung vorgenommen wurde. Die Beratung in der Fruehphase beginnt mit Einzel-und Gruppensitzungen und legt besonderen Wert auf die Neubeurteilung des Koerperbewusstseins, die Sexualitaet und die sexuellen Alternativen. Die Penisprothese wird waehrend der akuten Rehabilitationsphase kurz erwaehnt. Weitere Beratung auf Verlangen des Patienten nach Entlassung aus der Gruppe identifiziert solche Patienten, die weiteres Interesse an der Penisprothese haben. Geeignete chirurgische Kandidaten muessen: 1. ein stabiles Blasenprogramm, 2. eine neuerliche urologische Roentgenbewertung, 3. sterilen Urin zum Zeitpunkt der Inplantation haben; und 4. duerfen sie keine Dekubitalgeschwuere aufweisen. Alle praeoperativen Patienten muessen sich einem MMPI Test unterziehen und mit einem Sexualberater sprechen. Sowohl die halbstarre als auch die aufblasbare Penisprothese werden dem Patienten angeboten, begleitet von einer gruendlichen Besprechung mit Aufklaerungsschriften, die die Vor- und Nachteile beider Prothesen sowie chirurgische und postoperative Komplikationen darstellen. Den Patienten wird eine praeoperative parenterale antibiotische Diaet sowie eine ueberwachte antibiotische Reinigung der Genitalien verordnet. Chirurgische Massnahmen fuer jede Prothese werden besprochen. Nach dem Eingriff muessen die Patienten weiterhin Antibiotika einnehmen und sie duerfen 6 Wochen lang keinen Geschlechtsverkehr haben. Nach der Operation besuchen sie auch einen Sexualberater.

Insgesamt wurden 40 solcher Implantationen vorgenommen, 34 Patienten hatten eine halbstarre Implantation und 6 Patienten hatten eine aufblasbare Prothese. Drei Implantationen mussten nach einer Infektion entfernt werden. Dabei handelte es sich um Patienten mit einer halbstarren Implantation. Eine 'Paraphimosis', die eine sekundaere Beschneidung erforderlich machte, wurde festgestellt. Den Patienten wurden Fragebogen vorgelegt, um festzustellen, ob sich Ihre Erwartungen von der Implatation, die sie vor der Operation hatten, sowie eine gute Partnerakzeptanz erfuellt hatten. Die Ergebnisse werden beschrieben werden, erscheinen aber recht guenstig. Wir moechten die Auswahl guter Kandidaten fuer die Sexualimplantation betonen, um potentielle Komplikationen zu verringern und gute Ergebnisse sicherzustellen.

\section{References}

Berkman AH, Weissman R, Frielich M 1978 Sexual adjustment of spinal cord injured veterans living in the community. Archives of Physical Medicine and Rehabilitation 59:29-33.

Cole TM, Chilgren R, Rosenberg P 1978 New programme of sex education and counselling for spinal cord injured adults and health care professionals. Paraplegia 11:111-124.

EISENBERG MG, RUSTAD LC 1976 Sex education and counselling program on spinal cord injury service. Archives of Physical Medicine and Rehabilitation 57:135-140.

GolJi H 1979 Experience with penile prosthesis in spinal cord injury patients. Journal of Urology 121:288-289. 
Light JK, Scott FB 1981 Management of neurogenic impotence with inflatable penile prosthesis. Urology 4:341-343.

Rossier A, FAM BA 1981 Indication and results of semi-rigid penile prostheses in spinal cord injury patients: long term followup. Journal of Urology 131:59-62.

SCHULER M 1980 Sexual counselling for the spinal cord injured: A reivew of five programs. Journal of Sex \& Marital Therapy 241-250.

Smith AD, Sazama R, Lange PH 1980 Penile prostheses: adjunct to treatment in patients with neurogenic bladder. Journal of Urology 124:363-364.

Van ARsdalen KN, Klein FA, HackleR RH, et al. 1981 Penile implants in spinal cord injury patients for maintaining external appliances. Journal of Urology 126:331-332. 